\title{
CONVENTIONALISM AS A THEORETICAL BASIS FOR THE UNDERSTANDING OF THE NATURE OF ECONOMIC SECURITY IN THE ENTERPRISE
}

\author{
Yuriy Pogorelov \\ Department of accounting and audit \\ Poltava National Technical Yuri Kondratyuk University \\ 24 Pershotravneviy ave., Poltava, Ukraine, 36011 \\ YSPogorelov@gmail.com \\ Yevhen Ivchenko \\ Department of management and marketing \\ Volodymyr Dahl East Ukrainian National University \\ 59-A Radianskiy ave., Sieverodonetsk, Luhansk region, Ukraine, 93400 \\ Ivchenkoevg85@gmail.com
}

\begin{abstract}
The existence of different approaches for the understanding of the concept of economic security, taking into account its nominal nature as an economic and general scientific denotation, is actually, from the epistemological point of view, the basis for the application of conventionalism for explanation of the nature of the enterprise economic security, harmonization of such approaches and the links between them. It is shown, that nowadays the concept of economic security has a significant number of approaches for its interpretation.

The purpose of the article is to study theoretical approaches to understanding the economic security of the enterprise and the formation of a certain unified theoretical and methodological basis for understanding the economic security of the enterprise.

The methodological basis of the study, the results of which are presented in the article, is a set of methods of scientific research, general methods, techniques and principles, including comparison, monographic analysis, historical analysis, analysis and synthesis, abstract-logical analysis, classification, and systematization have been used.

It is shown, that nowadays the concept of economic security has a significant number of approaches for its interpretation. The correlation between such approaches can be considered either based on the shift of scientific paradigm (scientific revolution) by T. Kuhn [1] from the imperative to the synthetic approach, or based on the approach of the competition of scientific research programs by I. Lakatos [2] "security-development" and "security-safety". Each approach creates the preconditions for the formation of the understanding of economic security, which in the future serves as the basis for the development of the tools for its evaluation, provision and enhancement.
\end{abstract}

Keywords: conventionalism, economic security, competition, enterprise, economic system.

\section{Introduction}

Since the beginning of the 20th century, the category of economic security has become one of the fundamental categories in modern national and international economics. Since that time, all the levels of economic security, starting from the individual level, the level of individual enterprise to the level of national economy and the global level, have been of interest of scientists. Economic security is one of the most important components of national security at the level of national economy and state as a whole. It also provides competitiveness of national economy. Taking into account that the enterprise is the element of the economic system of the region and the state, at the level of the individual enterprise, its economic security creates the preconditions for the stable successful operation of the enterprise for a long period.

Since the 90 s of the 20th century, there has been a significant actualization of economic security issues for domestic enterprises in Ukraine. Such actualization is caused by the complication of institutional environment of their operation, its changing nature, the emergence of additional risks, threats, challenges, and by the fact that under the conditions of globalization the new nature of economic relations expand the market boundaries within which the enterprise operates. 
The urgency of economic security issues for domestic enterprises creates the necessity of its provision and support, which at the same time are based on understanding of the nature of the economic security in the enterprise and the theory for such understanding.

\section{Analysis of literary data and statement of the problem}

The relevance of the study of economic security is the interest of many domestic and foreign scholars. Some aspects of the study of the theoretical foundations of economic security are considered in the works [3-5].

Today, there are several approaches for understanding the economic security of the enterprise. According to the scientific literature $[6,7]$ there are two approaches for determining economic security: the first one is based on the use of concepts of threat and protection from threats; the second approach avoids the use of the notion of threat in the definition of security and is based on administrative or economic concepts (efficiency, reaching of the aim, functioning and development). A similar opinion is shared by scientists in their works [8-12] who consider that all concepts of understanding the economic security are divided into two groups: protection from various threats and the form of economic development of the enterprise.

A similar view is indicated in the work [13]: analyzing different approaches for the definition of this notion, it is concluded that the most of them represents two approaches: the first approach is based on the use of the concept of "threat", and the second one - on the concept of "profit" [13].

However, nowadays, such a dichotomous point of view regarding the essence of the economic security of the enterprise can be defined as outdated, since there is a great number of approaches for understanding the economic security of the enterprise.

The analysis shows that there are several approaches for understanding the economic security of an enterprise, and each of these approaches has its own justification and provides its own view on the essence of the economic security of the enterprise. Each of these approaches has the right to exist, a solid argument for understanding the economic security of the company, which determines the relevance of the study.

\section{Aim and tasks of research}

The article aims at substantiation and scientific enrichment of the following aspects:

1. Determining the content and relationship between approaches to understanding the economic security of enterprises.

2. Combining existing viewpoints on economic security of an enterprise and thus enrichment of its understanding in science of security.

3. Determining the practical value of the results of the study.

\section{Research Methodology}

The methodological basis of the study, the results of which are presented in the article, is a set of methods of scientific knowledge, general methods, techniques and principles, including comparison, monographic analysis, historical analysis, analysis and synthesis. The theoretical framework of the study is the fundamental provisions of conventionalism, economic securitology, the theory of management, the theory of the enterprise. The article uses the results of its own research and scientific works of domestic and foreign scientists.

\section{Results of the research}

In the epistemological sense, the economic security in an enterprise can have dual nature. On the one hand, it can be considered at the rather abstract level in the content of the thesaurus of modern securitology, taking into account the existing attributes of its nature. In this case, it requires agreement of the different points of view regarding to the nature and the content of the economic security in the enterprise. On the other hand, at the level of particular enterprise, economic security has quite pragmatic level of actualization and expresses itself in the absence of risks, threats, losses or the results of negative influence of the subjects of internal or external environment. In this case, the economic security in the enterprise and the concepts that explain it, fully correspond to the 
criterion of falsification of knowledge proposed by K. Popper [14]. Thus, the attempts to clarify the understanding and nature of the economic security in the enterprise are not an intrinsic value, but they are solely the basis for its support on a pragmatic level.

The current state of national securitology requires the formation of a certain unified theoretical and methodological basis for understanding the economic security in the enterprise. As a basis is proposed to choose conventionalism as an epistemological concept in scientific cognition. Conventionalism derived from Latin "conventio", which means "agreement", "contract". According to this concept, all non-contradictory scientific theories (as well as philosophical ones) are equally acceptable and none of them can be recognized as absolutely true, refuting others $[15,16]$. The founders of the concept of conventionalism are considered in the work $[15,16]$, but each of them considered different level of the conventionality of the provisions of scientific knowledge. For example, E. Leroy proposed an absolute conventionalism, within which all non-contradictory scientific theories concerning the same object of study are equal.

However, the absolute conventionalism leads actually to epistemological relativism. In this regard, G. Reale and D. Antiseri note [15], that when all the theories are conventional, it is useless to say about their objectivity. Moreover, the very fact of conventionality and consistency the scientist establishes on the bases of the categories defined by himself. So, absolute priority given to conventionalism leads to complete subjectivity in science and to impossibility of gaining knowledge, which has signs of objectivity. In addition, the absolute conventionalism by E. Leroy [15] provides coherence of all theoretical elements (if they are consistent), but completely does not give reasons for using of such knowledge at the pragmatic level.

A. Poincaré proposed more reasonable idea concerning conventionalism as the basis of scientific knowledge and its use in practice [16]. According to his point of view, the main provisions of any scientific theory are neither synthetic truths a priori nor a reflection of reality a posteriori. That is, A. Poincaré considered them as the result of the agreement between scholars. Their consistency is the only absolute condition for such provisions [16]. Subsequently, the conventionality of theoretical positions can be overcome or disproved on the basis of the falsification of such provisions (in the understanding of $\mathrm{K}$. Popper [14]), but this does not prevent from considering consistent theoretical concepts as hypotheses to the fact of such falsification.

Despite the fact, that historically the idea of conventionalism is relatively new (XIX-XX centuries), it has been quite successfully used in science for a long time. Any discipline is actually based on certain axioms that within this field of knowledge considered to be truthful without any evidence (moreover, the necessity and epistemological role of axioms follows directly the second K. Gödel's theorem about the incompleteness of formal system [17], and it does not prevent the development of a significant set of sciences). Classical Euclidean geometry is based on axiomatics of a point and straight lines in space, arithmetic is based on Peano axioms, set theory is based on (including) extensionality axiom, the classical Austrian School of marginalism is based on the fact of rational behavior of economic subject etc. Such axioms become the cornerstone of the entire branches of science, are used a priori and allow obtaining new theoretical and pragmatic knowledge, although they do not have complete theoretical proofs. Consequently, the use of conventionalism as the theoretical basis for understanding of economic security in no way contradicts the methodology of science and the scientific method of knowledge, on the contrary it allows combining and reconciling the existing achievements of various researchers.

It is expedient to reveal the content of economic security in the enterprise based on conventionalism. However, at first it is necessary to introduce briefly the historical aspect of the development of the sense of economic security as an independent category and economic security in the enterprise, as well as its relationship with other key concepts of the enterprise's activity.

The notion of economic security did not remain unchanged, and over time, the content of this concept was gradually enriched. In the countries of Western Europe, the term "economic security" appeared in the 1970's and was interpreted as "an economic method of ensuring of national security". A specific feature of the analysis of the problem of economic security, carried out by economists of the 1970s, was the transition from the concept of economic security, which was based on a military factor, to a concept in which economic security is a result of the state's inde- 
pendence from the foreign economic policy of other countries. At the same time, independence is based on a set of conditions and factors of the internal environment, the clarification of which the works of this period are devoted to $[5,7]$.

Another aspect of economic security at the macro level in the same historical period $(70 \mathrm{~s}$ of the twentieth century) is the close connection between the categories of security and the development of the national economy. World experience shows that even if the development of the economy was provided without ensuring of its security (Brazil in the 60's, Egypt and Poland in the 70's, Mexico in the 80's, Turkey, Thailand, Indonesia in the 90's. XX century, Argentina at the beginning of the XXI century), then it was predominantly unstable, and the period of economic growth did not last long and ended with the beginning of the economic crisis [18]. In this regard, A. Gumenyuk notes that economic security is the dominant or at least the most important characteristic of the economy, and in this case, the goal of economic development is to ensure its security [18]. However, it is impossible to agree fully with this point of view, since the absolutization of economic security, on the contrary, leads to restraining of the development of the economic system, which is presented in papers $[11,19]$. Thus, economic security is one of the keys, reference points in the national economy, although it is not a single.

It is necessary to note that economic security is closely connected with the development at all levels of economic relations. Economic security is connected directly with the development and it ensures its sustainability. Security is essential for the functioning and development of the economic system, and the development of the economic system creates preconditions for its security $[20,21]$. The close connection between economic security and the development of the enterprise one can see in the work of S. V. Kavun [22]. From his point of view, economic security implies sustainable development, balanced and continuous, which is achieved by using of all kinds of resources and opportunities, which guarantee their most effective use for the stable functioning and dynamic scientific, technical and social development, prevention of internal threats [22].

On the other hand, it is not necessary to recognize the economic security absolute, as a priority in the functioning of economic systems at various levels. The reason is that after achieving a certain level of economic security, further efforts and efforts to provide it in a certain system, on the contrary, prevent the development of this system. The attempts to provide economic security from a certain point in time contradict even positive changes. They become, according to terminology, the developmental inhibitor [19] and begin to create certain threats through the rigidity of the system of the economic security object, its low adaptability, the rejection of even positive transformations as they are always connected with certain risks. Paradoxically, but in this case, exactly the attempt to ensure the economic security of a particular system becomes that very factor which reduces security by itself. The reason is that it constrains the system, limits its adaptive reactions and implementation of even positive changes.

The economic security in the enterprise is directly connected with other important concepts of management such as competitiveness, the external environment, risks, threats, enterprise constancy, etc. $[5,11]$. They allow determining the place of security in a number of economic categories, its impact on the activities of the enterprise, causal and consequential field of economic security in the enterprise.

The existence of different approaches for understanding of the economic security in the enterprise $[11,12,23,24]$ and various generalizing approaches $[8,10,25]$ requires some coordination and the formation of a coherent, integrated viewpoint on this issue. Such an agreement is necessary, since the approaches mentioned above are not contradictory (without an additional epistemological basis), but they are still competing. Although some specialists in securitology (for example, L. Shulzhenko [26]) point out the lack of competition between the approaches for understanding of economic security, the content of approaches proves that such competition exists and requires its agreement (Fig. 1).

Continue to emerge new attempts to generalize existing points of view about the nature of economic security and to offer a comprehensive or convergent understanding of it. E. Ovcharenko in his work made an interesting attempt to generalize existing approaches for understanding of the economic security in the enterprise [10]. On the basis of the generalization of scientific approaches for the description of economic security in the enterprise it is concluded that conceptually all approaches are divided into two fundamentally different groups. The first one is based on the concept of security as 
a form of development; the second one is based on the concept of security as a form of confrontation of the subject of threats. O. V. Ilyashenko [8] has a similar point of view. She considers that all the conceptions for understanding of the economic security are divided into two groups: protection from various threats and the form of economic development of the enterprise. In fact, the idea of E. Ovcharenko [10] and O. Ilyashenko [8] is an important step in modern national securitology, because such an idea conventionally combines the economic security in the enterprise with its particular foundation: development or threats. Accordingly, in the first case, the state of the enterprise is described as a dynamic imbalance. The development becomes both a basis and an instrument for ensuring the economic security in the enterprise in its changing environment. In the second case, all the attention is paid not only to positive changes, but also to protection from negative changes such as threats.

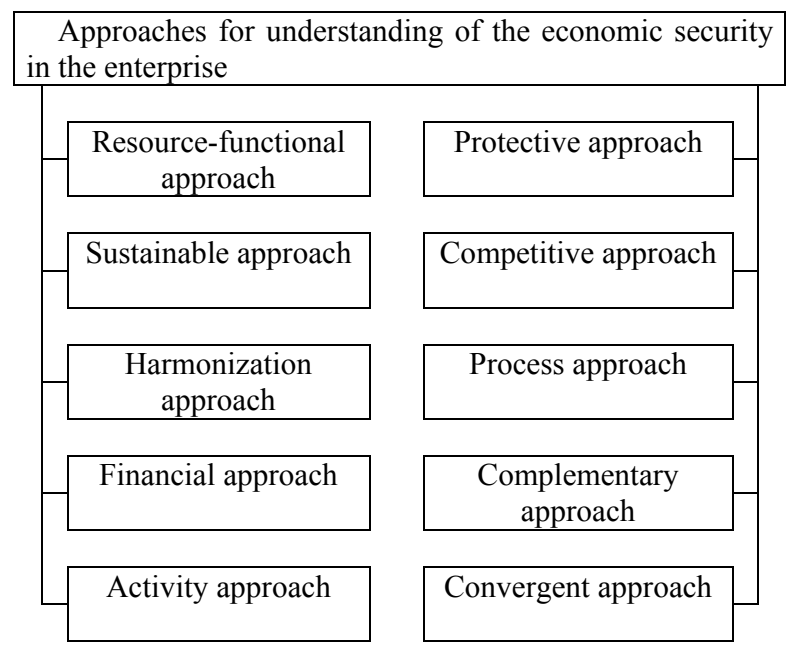

Fig. 1. Approaches for Understanding of the Economic Security in the enterprise Source: generalized by the author based on $[9,11,12,21,24]$

So, the analysis shows that there are several approaches for understanding of the economic security in the enterprise. All of them have the right to exist, as each of the approaches has a solid argumentation basis about understanding of the economic security in the enterprise. Within the concept of conventionalism the existence of several approaches does not call in question any of them, as such a situation in economic safety nowadays does not contradict epistemological principles in science and corresponds to the situation of competition of "research programs" by I. Lakatos [2]. When to consider the available approaches for understanding of the economic security in the enterprise from the epistemological point of view on the basis of conventionalism, then in fact the relationship between them can be described either within the "scientific paradigm" by T. Kuhn [1] or within the "research programs" by I. Lakatos [2]. The difference in the approaches of T. Kuhn [1] and I. Lakatos [2] regarding the existing points of view and individual approaches for understanding of the economic security in the enterprise is presented in Table. 1

Within the boundaries of the scientific paradigm of T. Kuhn [1], understanding of economic security is controversial. In fact, in the development of securitology there is a transition from one approach to another. The only one chosen approach for understanding of economic security actually makes it impossible to use another one. For example, the simultaneous understanding of economic security within the attribute characteristics of O. V. Ilyashenko [8] as a state, process and characteristics are rather complicated, for the subject of perception of economic security, it is necessary to choose a particular attribute and its use. The development of synthetic approaches, which found their enlightenment in various works $[8-10,25]$ is a way to overcome it.

In the frames of synthetic approaches, there was made an attempt to combine conventionally the existing points of view regarding to the economic security in the enterprise and thereby to enrich its understanding in security science. Such attempts are considered to be quite successful, at least a synthetic or convergent view on the essence of economic security has its prospects such as to form a 
comprehensive understanding of the economic security in the enterprise by combining existing approaches and to make it as a basis of the instrumental basis of economic security in the enterprise.

Table 1

The correlation between existing approaches for understanding of the economic security in the enterprise within the concepts of T. Kuhn and I. Lakatos

\begin{tabular}{|c|c|}
\hline $\begin{array}{l}\text { The approach of the shift of } \\
\text { the scientific paradigm by T. Kuhn }\end{array}$ & $\begin{array}{l}\text { The approach of competition of } \\
\text { I. Lakatos research programs }\end{array}$ \\
\hline $\begin{array}{l}\text { 1. Approaches based on imperative axiomatic concepts. } \\
\text { 2. Approaches based on attribute characteristics [18]. }\end{array}$ & $\begin{array}{l}\text { 1. Approaches for understanding security as a form of econom- } \\
\text { ic development of the enterprise. }\end{array}$ \\
\hline $\begin{array}{l}\text { 3. Synthetic approaches (complementary, convergent, conver- } \\
\text { gent-pragmatic) }\end{array}$ & $\begin{array}{l}\text { 2. Approaches for understanding security as a security against } \\
\text { a variety of threats }\end{array}$ \\
\hline
\end{tabular}

Source: proposed by the author based on [3, 4, 6, 8, 10, 12, 13, 24]

If to take the approach by I. Lakatos [2] as a basis for understanding of the economic security in the enterprise, it will be obvious that there is a question of competition between the dichotomous most widespread views on the nature of economic security - either it is a form of development or protection against threats. It is obvious that these approaches are contradictory in content and nature, although conventionally they are both internally consistent and well grounded. But at both theoretical and the pragmatic levels of securitology, the economic security subject must make its choice regarding to understanding of economic security. This choice will be used as a basis for assessing economic security, providing it, choosing the necessary tools, and so on.

\section{Discussion of the results}

Thus, the article deals with the possibility of using of different existing approaches for understanding of the content of economic security in the enterprise on the principles of limited conventionalism by A. Poincaré [16]. It gives the opportunity to determine the relationship between the approaches for understanding of the economic security in the enterprise, the possibility of their joint choice and connection in the contests within the conventional concepts of T. Kuhn [1] and I. Lakatos [2]. On the principles of conventionalism, it has been shown that the understanding of economic security is conventional-subjective. The reason is that the subject of economic security can take as a basis the existing theoretical positions. They can either change one another within the concept of the shift of the paradigm by T. Khun [1] from imperatively grounded understanding of economic security to synthetic or convergent its understanding, or such theoretical developments will compete conventionally with one another ("security-development" and "security-safety") if we take as a basis the concept by I. Lakatos [2].

Theoretical value of the research consists in generalization and structuring of the exploratory basis of the economic security in the enterprise, determining the relationship between its individuals, its provisions and the possibility of their joint use. The practical value of the research consists in the formation of a consistent, well-grounded understanding of economic security as a substantive basis in the development and use of tools for its evaluation, provision and improvement.

\section{Conclusions}

The following conclusions were made as a result of the realized studies:

1. There was defined the content of economic security of an enterprise within the framework of the conventional concepts of T. Kuhn and I. Lakatos (the concept of security as a form of economic development of an enterprise, the concept of security as protection from various threats).

2. Theoretical value of the research consists in generalization and structuring of the exploratory basis of the economic security in the enterprise, determining the relationship between its individuals, its provisions and the possibility of their joint use.

3. The practical value of the research consists in the formation of a consistent, well-grounded understanding of economic security as a substantive basis in the development and use of tools for its evaluation, provision and improvement. 


\section{References}

[1] Kuhn T. (2001). Struktura nauchnyih revolyutsiy. Moscow: AST, 15.

[2] Lakatos, I. (1995). Falsifikatsiya i metodologiya nauchno-issledovatelskih programm. Moscow: Medium, 236.

[3] Ianioglo, A., Polajeva, T. (2016 ). Origin and definition of the category of economic security of enterprise: a review. 9th International Scientific Conference "Business and Management 2016". doi: 10.3846/ bm.2016.46

[4] Mutchler, J. E., Shih, Y., Lyu, J., Bruce, E. A., Gottlieb, A. (2014). The elder economic security standard index ${ }^{\mathrm{TM}}$ : A new indicator for evaluating economic security in later life. Social Indicators Research. doi: 10.1007/s11205-014-0577-y

[5] Vasiltsev, T. G. (2008). Ekonomichna bezpeka pidpryiemnytstva Ukrainy: stratehiia ta mehanizmy zmitsnennia. Lviv: Aral, 384.

[6] Linnik, O. I., Artemenko, N. V. (2013). Stratehiia ekonomichnoi bezpeky pidpryiemstva yak faktor zmenshennia vplivu zovnishnih ta vnutrishnih zahroz. Visnyk of the NTU “KhPI”, Kharkiv, 67 (1040). 159-169.

[7] Vlasyuk, O. S. (2008). Teoriia i praktyka ekonomichnoi bezpeky v systemi nauky pro ekonomiku. Kyiv: RAND National Security Research Institute of Ukraine, 43-46.

[8] Ilyashenko, O. V. (2016). Mehanizmy systemy ekonomichnoi bezpeky pidpryiemstva. Kharkiv: Machulin, 503.

[9] Pogorelov, Yu. S., Vakhlakov, V. V. (2016). Peredumovy formuvannia konvergentno-prahmatychnoho pidhodu do rozuminnia ekonomichnoi bezpeky pidpryiemstva. European cooperation, 5 (12).

[10] Ovcharenko, Ye. I. (2015). Systema ekonomichnoi bezpeky pidpryieemstva: formuvannia ta tsilepokladannia. Lisichansk: PromEnergo, 483.

[11] Lyashenko, O. M. (2011). Kontseptualizatsiia upravlinnia ekonomichnoiu bezpekoiu pidpriemstva. EkonomIchna bezpeka pidpriemnitstva Ukraini: strategiya ta mehanizmi zmitsnennya.

[12] Kozachenko, G. V., Adamenko, T. M. (2015). Ekonomichna bezpeka pidpryiemstva: analiz naiavnyh vyznachen. Visnyk of Poltava University of Economics and Trade, 1 (69), 90-95.

[13] Zubok, M. I., Rubtsov, V. S., Yaremenko, S. M., Gusarov, V. G. (2012). Ekonomichna bezpeka subiektiv pidpryiemnytstva. Kyiv, 226.

[14] Popper, K. (1959). The logic of scientific discovery. London: Routledge.

[15] Reale, J., Antiseri, D. (2003). Zapadnaya filosofiya ot istokov do nashih dney. Ot romantizma do nashih dney. St. Petersburg: Pnevma, 880.

[16] Poincaré, A. (1990). O nauke. Moscow: Nauka,

[17] Uspenskiy, V. A. (1982). Teorema Giodelia o nepolnote. Moscow: Nauka, 110.

[18] Gumenyuk, A. M. (2014). Bezpeka strukturno-instytutsionalnoi transformatsii ekonomiky rehionu: teoretychni osnovy ta prykladni aspekty. Kyiv: National Institute for Strategic Studies (NISS), 468.

[19] Pogorelov, Yu. S. (2009). Modeliuvannia rozvytku pidpryiemstva. Current problems of the economy, 10 (100), 51-59.

[20] Moiseenko, I. P., Marchenko. O. M. (2011). Upravlinnia finansovo-ekonomichnoiu bezpekoiu pidpryiemstva. Lviv, 380.

[21] Poltorak, A., Volosyuk, Yu. (2016). Tax risks estimation in the system of enterprises economic security. Economic Annals-XXI, 158, 3-4(2), 35-38. doi: 10.21003/ea.V158-08

[22] Kavun, S. V. (2009). Systema ekonomichnoi bezpeky: metodolohichni ta metodychni zasady. Kharkiv, 300.

[23] Pogorelov, Yu. S. (2010). Pryroda, rushiini syly ta sposoby rozvytku pidpryiemstva. Kharkiv: AdvATM, 352.

[24] Prus, N. V. (2014). Systema ekonomichnoi bezpeky pidpryiemstva: poniattia, sutnist, pryntsypy. Global and national problems of the economy, 675-679. Available at: http://www.global-national.in.ua/ archive/2-2014/138.pdf

[25] Semenenko, I. (2016). Energy Security of Ukraine in the Context of Its Sustainable Development. Equilibrium, 11(3), 537-555. doi: 10.12775/EQUIL.2016.024

[26] Shulzhenko, L. E. (2014). Ekonomichna bezpeka stratehichnoho aliansu. Lugansk: Promotruk, 318. 